\title{
Revisiting Effects of Native Speakerism on Thai Teachers and Students in the Age of English as a Lingua Franca
}

\author{
Rutthaphak Huttayavilaiphan ${ }^{1}$ \\ ${ }^{1}$ Department of English, School of Liberal Arts, University of Phayao, Phayao, Thailand \\ Correspondence: Rutthaphak Huttayavilaiphan, Department of English, School of Liberal Arts, University of \\ Phayao, Phayao, Thailand.
}

Received: October 27, 2021

Accepted: November 10, $2021 \quad$ Online Published: November 11, 2021

doi: $10.5539 /$ elt.v14n12p8

URL: https://doi.org/10.5539/elt.v14n12p8

\begin{abstract}
Currently, the role of English language has changed from being a language used among native English speakers (NESs) to being a language spoken by people of various backgrounds or known as English as a lingua franca (ELF). This phenomenon has affected different aspects of global English usage and users across the world. However, in Thailand, this issue does not seem to be taken into account with regard to English language teaching (ELT) and learning practices as different ELT stakeholders continue to conform to traditional teaching methods related to NESs. This action is reflected in an English language ideology called 'native speakerism' which has long been entrenched in Thai society. It has repeatedly caused different problems for both Thai teachers and students of English language until the present day. This review article aims to demonstrate the impacts of the native speakerism ideology on Thai teachers and students of English language in the period of English as a global lingua franca. The article begins with an explanation of how the changes of role and status of English challenge traditional perspectives of English language and how the ELT industry around the world, including in Thailand, should adapt to such changes. Then, the article gives brief conceptualizations of native speakerism and its effects on English teachers and students. Finally, it moves on to discuss the native speakerism ideology in Thailand and reports different negative effects of native speakerism on Thai teachers and students of English language.
\end{abstract}

Keywords: native speakerism, English language teaching, English language learning, Thai teachers of English, Thai students of English, English as a Lingua Franca

\section{Introduction}

1.1 Changes of Role and Status of English Language and Their Effects on English Usage, Teaching, and Learning

Currently, the language in use, known as English, is different from that learned from books or in classrooms. Given the spread of English as a global language spoken by people across the world, many aspects related to it have been changed and modified to suit a variety of purposes. For example, there has been a change to the long-established truth concerning the number of dominant English speakers, as non-native English speakers (NNESs) have now outstripped native English speakers (NESs) by around four to one at present (Braine \& Selvi, 2018). This change has prompted many scholars to advocate re-nationalizing the ownership of English and other related issues including identity (Norton, 1997, 2018), standard language ideology (Tahmasbi, Hashemifardnia, \& Namaziandost, 2019; Widdowson, 1994), and the dichotomy of NESs and NNESs (Higgins, 2003; Holliday, 2013), which have long influenced how English is used by different groups of speakers around the world. Besides, there has been a shift in the role of English from it being a language mainly used among particular groups of NESs (or between NESs and NNESs) to being an international lingua franca (henceforth ELF) mostly spoken among NNESs themselves (Jenkins, 2006). This ELF phenomenon has posed many challenges to traditional perspectives of English language including World Englishes (WEs) (Note 1) (Kachru, 1992). This is a term which has long been employed to describe English users and usages worldwide. That is to say, as WEs view English as bounded by location and nation, it seems thus incapable of explaining the process of ELF communication, which is usually fluid and unbounded since it consists of bi- and multilingual speakers whose community or setting could be shifting. Such users are frequently not connected with a specific country, for example, ELF encounters on the Internet and Facebook (Cogo, 2012). 
Therefore, to respond to these changes, several researchers have recommended that other features related to English language should be readdressed for the benefit of using, teaching, and learning this language. To illustrate, Graddol $(1997,2006)$ argued that, given the relative decline in the number of NESs, NNESs need to determine their world of English language and adapt such changes to their own ways of using English. Brumfit (2001, p. 116) also suggested, when NESs are in a marginal position for language use, it seems logical that the language practices, language maintenance, as well as language ideologies and beliefs be adjusted to associate with this phenomenon, or "at least in so far as non-native speakers use the language for a wide range of public and personal needs". Moreover, some other scholars even responded to these changes by suggesting important characteristics of ELF communication in English language education (e.g., Baker, 2015; Bowles, 2016; Cogo, 2016). This includes Bowles (2016) who recommended focusing on numerous features that are related to ELF communication (such as pragmatics, comprehensibility, and cultural sensitivity), as such features are crucial for enhancing learners' consciousness of the complex procedure of communication involved in English multicultural connections.

\subsection{Native Speakerism as a Dilemma for ELT Practice in Thailand}

However, in the reality of the English language teaching (ELT) practices of Thailand, it seems that proper attention is paid neither to the shifting role of the English language nor to the complexity of ELF communication. Simply put, many Thai ELT stakeholders (e.g., government sectors and educational institutions) tend to continue conforming to the NESs-oriented models of English teaching and learning. This cultivates Thai people's beliefs that they should only learn English with NESs or try to master what is called native-like proficiency (Ambele \& Boonsuk, 2020; Baker \& Jarunthawatchai, 2017; Inkaew, 2018; Watson Todd, 2006). This action has reflected the 'native speakerism' ideology which has long been influencing different Thai people's dilemmas about English practice, although several plurilingual and multilingual research studies have been performed to disprove the inherent superiority of NESs and their teaching models (e.g., Baker \& Jarunthawatchai, 2017; Boonsuk, Ambele, \& McKinley, 2021; Kadowaki, 2018; Saengngoen, 2014; Suizu \& Aung, 2018; Tarrayo, Ulla, \& Lekwilai, 2021).

\subsection{Objectives of the Article}

As it seems difficult to eliminate the native speakerism ideology which has long been entrenched in Thai society from Thai ELT practices, the present article aims to raise this issue for discussion, as well as to revisit its negative effects on Thailand's English language education, especially in the present period when Thai people use English as a lingua franca or ELF with other groups of NNESs more than as a foreign language (EFL) with NESs (Ambele \& Boonsuk, 2020; Baker, 2012; Baker \& Jarunthawatchai, 2017; Kongkerd, 2013; Nomnian, 2014). Furthermore, this paper seeks to provide a comprehensive review of the topic of native speakerism in Thailand, which seems to be understudied regardless of the fact that various studies have demonstrated its impact on teaching and learning English in this country. The article begins with a review of definitions of native speakerism and its effects on teachers and students who are often affected by its ideology (Holliday, 2006, 2017; Lowe \& Kiczkowiak, 2016; Lowe \& Pinner, 2016). Then, it moves on to focus on native speakerism in Thailand as well as its impacts on Thai teachers and students of English based on the findings and discussions of ELT research undertaken in Thailand from the late twentieth century to the present.

\section{Literature Review}

\subsection{Native Speakerism and Its Effects on Non-Native Teachers and Students of English Language}

Native speakerism is one of the most broadly debated ideologies in the field of ELT. It was conceptualized by Holliday (2005) to discuss an inherent superiority of NESs over NNESs in terms of teaching the English language. Lowe and Pinner (2016) considered that the ideology of native speakerism developed from an earlier concept called 'linguistic imperialism'. This was suggested by Phillipson (1992) and criticized how the power centers of the West exercise control over the language learning and language use of developing nations. The concept is particularly noted for several myths, which have been accountable for reinforcing this neo-imperialist agenda. Native speakerism is also claimed to be an extension of the false, ill conceptualized, and ideologically constructed notions of 'native speaker' and 'non-native speaker' of Davies (1991), which caused several negative consequences for non-native speakers of English across the world. For instance, Holliday (2005, p. 6) regarded that, because NESs are generally perceived to be representative of the "western culture from which springs the ideals both of the English language and English language teaching methodology", they are thus considered to be better language models and to embody a greater Western teaching methodology than NNESs. This issue has consequently led to extensive use of an 'us' and 'them' dichotomy where non-native speaker teachers and students (henceforth NNTs and NNSs) are perceived as culturally inferior and in need of training in 
the 'correct' Western approaches of learning and teaching (Houghton \& Rivers, 2013; Lowe \& Kiczkowiak, 2016).

Focusing more on the negative effects of the native speakerism ideology on NNTs, Holliday (2005) stated that, for NNTs, the ideology can directly affect their professional life, from the presentation of the language to employment policy. The former case means that NNTs often struggle to move away from basing their professional knowledge on 'American' or 'British' language and culture to a broader grounding in the sociolinguistics and cultural studies of how the backgrounds of their students related to a wider cosmopolitan world (Holliday, 2017). For example, Murata and Iino (2017) demonstrated teachers' struggle to teach English as a Medium Instruction (EMI) when the 'E' of EMI forces them to teach English based on the NESs' standard, such as accent and assessment, and this has contributed to their ineffective teaching and preparation within classrooms. In the latter case, it was argued that NNTs often suffer from the underlying perception called 'othering' (Holliday, 2006, 2017; Holliday \& Aboshiha, 2009) when people from outside the English-speaking West perceive them as someone who does not possess attributes that NESs should have (e.g., regional or religious cultural stereotypes). This perception has caused them to be labeled, for example, as someone who is culturally indirect or traditionally uncritical and unthinking (Kubota, 2001; Pennycook, 1994). Even worse, based on this othering perception, NNTs often encounter the discriminatory employment practices that go far beyond the English-speaking West, where all kinds of language teaching organizations and their customers usually display an albeit misguided favorite for native-speaker teachers (NTs) (e.g., Dervić \& Bećirović, 2019; Flynn \& Gulikers, 2001; Li \& Campbell, 2009).

As for NNSs, one of the ways that the native speakerism ideology can affect them occurs when their institutions hire NTs who cannot create classrooms related to learning the nature and culture of their students, leading to their poor learning outcomes. To support this point, many studies have confirmed that some aspects of NTs can impede students' learning. For example, Benke and Medgyes (2005) showed that, although NTs were perceived as friendly, lively, great models for imitation, and skilled at stimulating students to use language, their speech could be difficult for NNSs to understand. More importantly, their differing linguistic and cultural background could inhibit students' learning. Walkinshaw and Oanh (2014) also reported on different aspects of NTs that could hinder students' learning ability including having cultural differences, having difficult-to-comprehend speech, lacking qualifications and experience, being unable to speak students' first language, and lacking the proficiency to teach grammar and lexis well.

Another effect of the native speakerism ideology on NNSs comes in the form of NES-based teaching materials. Galloway (2017) pointed out that ELT materials used in many non-native English-speaking countries either by NTs or NNTs follow the communicative language teaching (CLT) approach, which aims to showcase 'authentic' language to NNSs. However, in fact, such materials tend to indirectly encourage native concepts of accuracy, where authenticity seems to be identical with native English. Given this point, when NNSs produce something that is different from these materials, such productions will be called 'erroneous' or 'incomplete' language, which require remediation based on the second language acquisition theory (Cook, 2002). Galloway (2017) stated that this judgment is unfortunate for students as, in practice, the mistakes may not necessarily impede communication, especially in ELF encounters where negotiations and accommodations are employed.

\subsection{Native Speakerism in Thailand}

As stated earlier, Thailand is a country which has long been affected by the native speakerism ideology (Boriboon, 2011; Tassev, 2021b). The beginning of the spread of this ideology among Thai people may be traced back to the eighteenth century when the NESs' ways of using English were first brought to be used and learned in the country among the elite (Sukamolson, 1998). Consequently, English became a sign of a high position in Thai culture (Eiewsriwong, 2004). For Thai people, learning and using English like NESs carries an elitist value for the prestige of themselves and their family existing up until the present day (Oda \& Toh, 2018). Another reason why Thailand still remains so native-speaker focused today may be the Thai government's substantial promotion of the NESs or Western standard of using English in Thai ELT. For example, it invited the British Council to develop Thai teachers' teaching and material practices (Methitham \& Chamcharatsri, 2011). These reasons have meant the native speakerism ideology has continued its role and power in Thai society and, at the same time, this ideology has influenced several negative effects on Thai teachers and students of English as discussed below.

\subsubsection{Negative Effects of Native Speakerism on Thai Teachers of English Language}

According to Holliday $(2005,2006)$, non-native teachers (NNTs) are one of the main groups of ELT stakeholders who experience negative effects from the native speakerism ideology. The situation in Thailand can 
confirm this statement, as many researchers have discussed how Thai teachers of English can suffer from this ideology both in terms of teaching practice and employment policy. Concerning teaching practices, Methitham (2014) expressed that Thai teachers of English have always been required to conform to a specific set of theoretical ideologies and classroom methods provided by NESs. This issue has impeded their teaching practices as they cannot freely choose their own methodological approaches, plan their curriculum, or make any instructional decision consistent with their knowledge and perception. Also, it has often been discussed that Thai teachers have encountered teaching difficulties due to this issue, in particular when some NESs' teaching approaches are irrelevant to their teaching contexts. For instance, Inprasit (2016) reported that Thai teachers found it difficult to teach English based on the communicative language teaching (CLT) approach, which is based on the NESs' model. This is because some contents and focuses of CLT are not relevant to their students' learning context, such as a mismatch between the exercise and students' context. Moreover, Darasawang and Watson Todd (2012) discovered that, because of the mismatch between the given policy (e.g., the National Education Act 1999 which emphasizes English reading) and their pedagogical beliefs, many Thai teachers often have to reject following, or even have to modify, such policy to suit their teaching context for the benefits of their students.

Another effect of the native speakerism ideology on teaching practices occurs when Thai teachers' accents were considered less favorable among students in classrooms than the accents of NTs. Despite many researchers having proved that the English accents of Thai teachers are easier and clearer to understand than the accents of NTs for Thai students (Rattanaphumma, 2013; Suksiripakonchai, 2013; Tassev, 2020, 2021a, 2021b), their student participants still viewed NESs' accents as more intelligible and authentic. For instance, Tassev (2021a) presented the finding that although there appeared to be a mismatch between the levels of intelligibility and comprehensibility of the English accents of NTs, adult Thai students still focused more on intelligibility (i.e., words) rather than on comprehensibility (i.e., meaning). This can be a problem for their future English communication as successful English communicators tend to require both of these aspects, not just one of them (Jung, 2010).

Consequently, when Thai teachers do not feel free in their own teaching practices, are incapable of performing English teaching tasks based on the NESs' standard or receive less favor in classrooms, their confidence, trust, and self-esteem in their profession can be reduced (Methitham, 2014). To support this argument, Methitham (2012) illustrated that many of his teacher participants thought that Thai teachers of English often lack certain linguistic competence or are unable to do teaching tasks like NTs (e.g., teaching English slang words, idioms, or jokes). Therefore, in order to compensate for such deficiency, it seems fair for the Thai teachers if their institutions hire NTs to help to teach Thai students. This result can be linked to some other studies that also explored the proposition that many Thai teachers viewed NESs as the ideal English teachers because this group of English speakers is the most competent in English language and culture (e.g., Methitham, 2009; Suwanarak, 2010). Even worse, with this thought, some Thai teachers were even reluctant to develop their own teaching materials and kept using commercial materials produced in native English-speaking countries (Huttayavilaiphan, 2019).

The last effect of the native speakerism ideology on Thai teachers' practices could be their negative attitudes towards English varieties. This argument can be supported by Jenkins (2005b) who noted that personal and teaching experiences are some of the factors influencing teachers' attitudes towards particular issues in their teaching. For example, in a study by Prabjandee (2020), some of his teacher participants showed a negative perception towards Filipino English after their interactions with Filipino teachers at their schools. At the same time, they perceived the NESs' accents (e.g., British accent) as more acceptable than other varieties (e.g., Singaporean and Thai accents). Another example of this issue can be seen in the author's study conducted in 2019 to explore the beliefs about ELT of a group of Thai university teachers (Huttayavilaiphan, 2019). The result of this study tended to view that the longer the teachers practiced teaching based on the NESs' models (e.g., grammar and pronunciation) can contribute to their negative attitudes towards other kinds of English which are different from the NESs' norms. To illustrate, according to the results of different research tools (i.e., interview, focus group, and observation), one of the Thai teacher participants, who continued focusing on teaching grammar and pronunciation based on the NESs' standard for almost 30 years, viewed other varieties of English (e.g., Filipino and Chinese English) as non-standard or even unacceptable English and suggested such varieties be seriously corrected to be like the English of NESs.

Finally, apart from teaching practices, an employment policy which gives priority to NESs has also had negative effects on Thai teachers. One of its effects can be seen when many of Thailand's institutions seek to hire and offer a higher salary to NTs than NNTs (e.g., Filipino and Thai teachers). For example, Methanonpphakhun and 
Deocampo (2016) reported that, in 2011, the Office of the Basic Education Commission (OBEC) sought to hire almost 300 NESs to teach in primary and secondary schools. Their proposal offered a salary of 83,000 baht per month for each NT while the salary range of Thai teachers was only between 9,000 and 15,000 baht. Although many Thai teachers showed an understanding of this salary differential based on reasons such as attracting and motivating them to come to work in Thailand and serving the needs of their customers who are students and parents, some Thai teachers viewed this issue as an 'inequitable hiring policy', a 'prejudice', and a 'sign of serious discrimination' which is difficult to eliminate (Methitham, 2012). Furthermore, it was found that this issue of different salary rates is also linked with the issue of 'unfair qualifications' and 'double hiring standard'. That is, some Thai teachers argued that many NESs had not graduated nor did they hold any certificates related to English language teaching (ELT) or English as a second language (ESL), yet they were still hired to teach Thai students. However, when it comes to NNTs including Thai teachers, the recruitment process becomes stricter (e.g., requiring a master's degree in a relevant field) (Comprendio \& Savski, 2020; Phothongsunan \& Suwanarak, 2008).

\subsubsection{Negative Effects of Native Speakerism on Thai Students of English Language}

Thai students have also been affected by the native speakerism ideology in many ways. The first effect can be seen when the NESs' ELT models used by their teachers are irrelevant to their nature and culture of learning, leading to their displeasure about the learning outcomes (Kongkerd, 2013; Methitham, 2011, 2014; Teng \& Sinwongsuwat, 2015). For example, Methitham (2014) stated that the CLT approach, which is based on the NESs' standard and has been heavily promoted by the Thai government, has ignored Thai students' voices and identities in the learning process. This is because, according to Kumaravadivelu (2003 cited in Methitham, 2014), the CLT approach tends to encourage learners to have a communicative ability which is suitable for "the specific purpose culturally empathizing if not culturally assimilating, with native speakers of English" (p. 543). To support this point, Pongsirijan, Wongrak, Kookiattikoon, and Puangsuk (2019) demonstrated that in classrooms that employ the CLT approach to teach Thai students, some common kinds of responses among Thai people (e.g., silence and smile) may not be counted as a proper method of English communication. In addition, Kongkerd (2013) mentioned that the use of CLT, which is a learner-centered approach, does not appear to suit the Thai culture, since many of Thai English teachers were acquainted with being at the center of the classroom and acting as knowledge providers, while the students were expected to listening to teachers and taking a role as knowledge receivers in their method of learning in the classroom.

The high expectation of NTs in English classrooms is the second effect of the native speakerism ideology on Thai students. That is to say, based on Methanonpphakhun and Deocampo (2016), some teachers who come from native English-speaking countries will set a high standard in English teaching and learning in their classrooms. Often, when Thai students have low levels of English or cannot achieve some tasks in classrooms, they will disappoint their NTs. This issue may be linked with Kongkerd (2013) who pointed out that, in many Thai classrooms, English teachers use the NESs' models of English pronunciation to teach and test Thai students and expect their students to pronounce accurately in accordance with them. When their students are unable to do so (e.g., to pronounce / $/$ /, in the word "the"), not only will their teachers feel dissatisfied, but also the students themselves can feel embarrassed, unconfident, or even demotivated to continue learning English.

The native speakerism ideology can also contribute to Thai students' lack of awareness of English variation. Jenkins (2005a) noted that Thailand encounters the problem of an idealistic model of the English language curriculum and the native speaker misconception which consequences in a lack of awareness of the broader diversities of English. Some other scholars also posited that many Thai students lack an awareness of the existence of other English varieties because their English classrooms, which conform to the NESs' models, encourage them to perceive that only British English and American English are correct (Boonsuk et al., 2021; Passakornkarn \& Vibulphol, 2020; Saengboon, 2015; Snodin \& Young, 2015). For this issue, Boonsuk et al. (2021) described that the NES-oriented teaching approach used in Thai classrooms has led to their student participants' lack of awareness of the new changing roles of English as they kept relying on native norms in classrooms. Passakornkarn and Vibulphol (2020) also showed that given that their student participants had been mainly exposed to the NESs' English, they were thus unaware of English variations. This means that when their English is different from the English of NESs, they will have low self-confidence and fear of speaking English, either inside or outside their classrooms.

Lastly, similar to the case of Thai teachers, when Thai students have long been exposed to the NESs' models in classrooms, they may cultivate negative attitudes towards varieties of English including the English of their own society. For example, Kalra and Thanavisuth (2018) found that among eighty Thai students many expressed negative attitudes towards some Asian accents (e.g., Burmese and Japanese accents) because such accents were 
thought to be unfriendly, boring, lazy, difficult to comprehend, and different from the NESs' accents. In addition, Jindapitak and Teo (2012) reported that Thai university students who participated in their study not only lacked awareness of varieties of English, but also possessed negative attitudes towards other English varieties (e.g., Filipino English, Indian English, Japanese English, and Thai English). In particular, with regard to Indian English, which is one of the nativized or institutionalized Englishes based on Kachru (1992), the student participants rated this variety as inferior to American and British English in all attributes including impressiveness, gentleness, confidence, friendliness, generosity, smartness, competence, and educatedness. Even worse, Tananuraksakul (2017), who used a two-stage investigation of Thai students' attitudes towards their own English accent, discovered that in both stages 1 and 2 their participants believed that speaking English like NESs was very important. For this reason, the students thus expressed negative attitudes towards their own accented speech which they found was embarrassing and non-native. Besides, as shown by Ambele and Boonsuk (2021), while a majority of their student participants expressed a positive attitude towards their own Thai-English accent, some still wanted to have a native-like accent. For these students, the Thai-English accent was seen to be unsatisfactory, local, primitive, non-standard, non-American, non-British, broken, bad, unintelligible, and even shameful.

\section{Conclusion}

To summarize, this article aimed to revisit the effects of the native speakerism ideology on Thai teachers and students of English language in the period of English as a global lingua franca. It began by explaining how the changes to the role and status of English challenged the traditional perspectives related to this language and how the ELT industry around the world, including Thailand which has remained so native-speaker focused, should be adapted to suit such changes. The article then re-examined conceptualizations of the native speakerism ideology and its negative effects on teachers and students of English language. Finally, the article focused on how the native speakerism ideology affects Thai teachers and students of English language.

For Thai teachers, the findings and discussions of different Thailand-based research supported Holliday (2005, 2006), who conceptualized the native speakerism ideology and pointed out its negative effects on NNTs in both teaching and employment practices. In terms of teaching practices, the native speakerism ideology can contribute to their teaching difficulties, receiving less favor in classrooms, low self-confidence and self-esteem, and negative attitudes towards other varieties of English. Concerning the employment practices, the research presented that many Thai institutions and recruitment agencies often seek to hire NTs and offer them higher salary rates than Thai teachers, even though many NTs do not hold any English teaching certificates. This issue could be connected with the issues of an inequitable and double-standard hiring policy as well as prejudice and discrimination. As for Thai students, the previous Thailand-based articles discussed the fact that the native speakerism ideology can affect Thai students' learning, causing difficulties especially when their NTs' teaching practices, high expectations, and the NES-based materials used in classrooms (by either NTs or NNTs) are irrelevant and unsupportive of their learning characteristics and culture. Also, it was perceived that when Thai students have long been exposed to the NESs' standard, they can lack, or even have negative attitudes towards, varieties of English including their own.

\section{References}

Ambele, E. A., \& Boonsuk, Y. (2020). Voices of learners in Thai ELT classrooms: a wake up call towards teaching English as a lingua franca. Asian Englishes, 23(2), 1-17. https://doi.org/10.1080/13488678.2020.1759248

Ambele, E. A., \& Boonsuk, Y. (2021). Thai Tertiary Learners' Attitudes towards Their Thai English Accent. PASAA, 6 .

Baker, W. (2012). English as a lingua franca in Thailand: Characterisations and implications. English in Practice: Working Papers of the Centre for Global Englishes, 1(1), 18-27.

Baker, W. (2015). Culture and identity through English as a lingua franca: Rethinking concepts and goals in intercultural communication (Vol. 8). Walter de Gruyter $\mathrm{GmbH} \&$ Co KG. https://doi.org/10.1515/9781501502149

Baker, W., \& Jarunthawatchai, W. (2017). English language policy in Thailand. European Journal of Language Policy, 9(1), 27-44. https://doi.org/10.3828/ejlp.2017.3

Benke, E., \& Medgyes, P. (2005). Differences in teaching behaviour between native and non-native speaker teachers: As seen by the learners. In E. Llurda (Ed.), Non-native language teachers (pp. 195-215). Springer. https://doi.org/10.1007/0-387-24565-0_11 
Boonsuk, Y., Ambele, E. A., \& McKinley, J. (2021). Developing awareness of Global Englishes: Moving away from 'native standards' for Thai university ELT. System, 99, 1-12. https://doi.org/10.1016/j.system.2021.102511

Boriboon, P. (2011). Language, ideology and domination: Problems of English language teaching in Thailand and solutions. Songklanakarin journal of social sciences and humanities, 17(6), 23-59.

Bowles, H. (2016). ELF-Oriented Pedagogy: Conclusions. In Bowles, H. \& Cogo, A. (Eds.), International Perspectives on English as a Lingua Franca. International Perspectives on English Language Teaching (pp. 194-208). Springer. https://doi.org/10.1057/9781137398093_11

Braine, G., \& Selvi, A. F. (2018). NNEST Movement. In J. I. Liontas, T. International Association \& M. DelliCarpini (Eds.), The TESOL Encyclopedia of English Language Teaching (pp. 1-6). https://doi.org/10.1002/9781118784235.eelt0039

Brumfit, C. J. (2001). Individual Freedom in Language Teaching: Helping Learners to Develop a Dialect of their Own. Oxford: Oxford University Press.

Cogo, A. (2012). English as a lingua franca: Concepts, use, and implications. ELT journal, 66(1), 97-105. https://doi.org/10.1093/elt/ccr069

Cogo, A. (2016). English as a Lingua Franca: Descriptions, domains and applications. In H. Bowles \& A. Cogo (Eds.), International Perspectives on English as a Lingua Franca (pp. 1-12). Springer. https://doi.org/10.1057/9781137398093_1

Comprendio, L. J. E. V., \& Savski, K. (2020). 'Asians' and 'Westerners': examining the perception of '(non-) native'migrant teachers of English in Thailand. Journal of Multilingual Multicultural Development, 41(8), 673-685. https://doi.org/10.1080/01434632.2019.1630419

Cook, V. (2002). Portraits of the L2 user. Clevedon: Multilingual Matters. https://doi.org/10.21832/9781853595851

Darasawang, P., \& Watson Todd, R. (2012). The effect of policy on English language teaching at secondary schools in Thailand. In Ee-Ling Low \& Azirah Hashim (Eds.), English in Southeast Asia: Features, policy and language in use (pp. 207-220). https://doi.org/10.1075/veaw.g42.17dar

Davies, A. (1991). The native speaker in applied linguistics. Edinburgh: Edinburgh University Press.

Dervić, M., \& Bećirović, S. (2019). Native and Non-Native EFL Teachers Dichotomy: Terminological, Competitiveness and Employment Discrimination. Journal of Language Education, 5(3), 114-127. https://doi.org/10.17323/jle.2019.9746

Eiewsriwong, N. (2004). Obstacles of learning English outside classroom in Thai society. Pasaa Parithat, 21, 4-9.

Flynn, K., \& Gulikers, G. (2001). Issues in hiring nonnative English-speaking professionals to teach English as a Second Language. CATESOL Journal, 13(1), 151-161.

Galloway, N. (2017). ELF and ELT teaching materials. In J. Jenkins, W. Baker, \& M. Dewey (Eds.), The Routledge Handbook on English as a Lingua Franca (pp. 468-480). London and New York: Rouledge. https://doi.org/10.4324/9781315717173-38

Graddol, D. (1997). The future of English. Oxford: The British Council.

Graddol, D. (2006). English next (Vol. 62). British council London.

Higgins, C. (2003). "Ownership" of English in the Outer Circle: An Alternative to the NS-NNS Dichotomy. Tesol Quarterly, 37(4), 615-644. https://doi.org/10.2307/3588215

Holliday, A. (2005). The struggle to teach English as an international language. Oxford University Press.

Holliday, A. (2006). Native-speakerism. ELT Journal, 60(4), 385-387. https://doi.org/10.1093/elt/cc1030

Holliday, A. (2013). The Struggle to Teach English as an International Language-Oxford Applied Linguistics. Oxford, UK. Oxford University Press.

Holliday, A. (2017). Native-speakerism. In J. I. Liontas (Ed.), TESOL Encyclopedia of English Language Teaching. Wiley Blackwell. https://doi.org/10.1002/9781118784235.eelt0027

Holliday, A., \& Aboshiha, P. (2009). The denial of ideology in perceptions of 'Nonnative Speake' teachers. TESOL quarterly, 43(4), 669-689. https://doi.org/10.1002/j.1545-7249.2009.tb00191.x 
Houghton, S. A., \& Rivers, D. J. (2013). Native-Speakerism in Japan: Intergroup Dynamics in Foreign Language Education. In S. A. Houghton \& D. J. Rivers (Eds.), Introduction: Redefining Native-Speakerism (pp. 1-14). Multilingual Matters. https://doi.org/10.21832/9781847698704

Huttayavilaiphan, R. (2019). Thai university teachers' beliefs about English language teaching and their awareness of Global Englishes: A study of relationship and impact on teaching practices (Doctoral Degree). University of Southampton, University of Southampton.

Inkaew, M. (2018). An Exploration of English as a Lingua Franca Communication: A Case Study of How English is Used as a Lingua Franca among Non-native Speakers for Mutual Understanding in an International Golf Tournament Operation in Thailand. REFLections, 25(2), 42-58.

Inprasit, C. (2016). Thai native teachers' experiences of using communicative language teaching in extended education schools (Master Degree). Thammasat University, Thailand.

Jenkins, J. (2005a). English as a lingua franca: Past empirical, present controversial, future uncertain. In J. Foley (Ed.), New Dimensions in the Teaching of Oral Communication: Proceedings of the 40th SEAMEO RELC International Seminar (pp. 1-19). Singapore: SEAMEO Regional Language Centre.

Jenkins, J. (2005b). Implementing an international approach to English pronunciation: The role of teacher attitudes and identity. Tesol Quarterly, 39(3), 535-543. https://doi.org/10.2307/3588493

Jenkins, J. (2006). Current perspectives on teaching world Englishes and English as a lingua franca. Tesol Quarterly, 40(1), 157-181. https://doi.org/10.2307/40264515

Jindapitak, N., \& Teo, A. (2012). Thai tertiary English majors' attitudes towards and awareness of World Englishes. Journal of English Studies, 7.

Jung, M. Y. (2010). The Intelligibility and Comprehensibility of World Englishes to Non-Native Speakers. Journal of Pan-Pacific Association of Applied Linguistics, 14(2), 141-163.

Kachru, B. B. (1992). Teaching world Englishes. In B. B. Kachru (Ed.), The other tongue: English across cultures (Vol. 2, pp. 355-365). University of Illinois Press.

Kadowaki, K. (2018). Japanese native speaker teachers at high schools in South Korea and Thailand. In S. A. Houghton \& K. Hashimoto (Eds.), Towards Post-Native-Speakerism (pp. 97-112). Springer. https://doi.org/10.1007/978-981-10-7162-1_6

Kalra, R., \& Thanavisuth, C. (2018). Do you like my English? Thai students' attitudes towards five different Asian accents. Arab World English Journal Volume, 9(4), 281-294. https://doi.org/10.2139/ssrn.3308293

Kongkerd, W. (2013). Teaching English in the era of English used as a lingua franca in Thailand. Executive Journal, 33(4), 3-12.

Kubota, R. (2001). Discursive construction of the images of US classrooms. Tesol Quarterly, 35(1), 9-38. https://doi.org/10.2307/3587858

Kumaravadivelu, B. (2003). A postmethod perspective on English language teaching. World Englishes, 22(4), 539-550. https://doi.org/10.1111/j.1467-971X.2003.00317.x

Li, M., \& Campbell, J. (2009). Accessing employment: Challenges faced by non-native English-speaking professional migrants. Asian Pacific Migration Journal, 18(3), 371-395. https://doi.org/10.1177/011719680901800303

Lowe, R. J., \& Kiczkowiak, M. (2016). Native-speakerism and the complexity of personal experience: A duoethnographic study. Cogent Education, 3(1), 1-16. https://doi.org/10.1080/2331186X.2016.1264171

Lowe, R. J., \& Pinner, R. (2016). Finding the connections between native-speakerism and authenticity. Applied Linguistics Review, 7(1), 27-52. https://doi.org/10.1515/applirev-2016-0002

Methanonpphakhun, S., \& Deocampo, M. F. (2016). Being an English language teacher: A narrative analysis of ten foreign teachers in Thailand. The New English Teacher, 10(1), 1-19.

Methitham, P. (2009). An exploration of culturally-based assumptions guiding ELT practice in Thailand, a non -colonized nation. (Ph.D.), Indiana University of Pennsylvania, Ann Arbor. Retrieved from https://www.proquest.com/dissertations-theses/exploration-culturally-based-assumptions-guiding/docview/ $305056748 /$ se-2?accountid $=140718$

Methitham, P. (2011). English as a modern-day Trojan horse: The political discourses of English language teaching. Journal of Humanities, Naresuan University, 8(1), 13-30. 
Methitham, P. (2012). White prestige ideology and its effects on ELT employment in Thailand. The International Journal of the Humanities: Annual Review, 9(4), 145-156. https://doi.org/10.18848/1447-9508/CGP/v09i04/43188

Methitham, P. (2014). Survey the landscape of ELT in Thailand: Offering new possibility for change. Paper presented at the WEI international academic conference proceedings.

Methitham, P., \& Chamcharatsri, P. B. (2011). Critiquing ELT in Thailand: A reflection from history to practice. Journal of Humanities, Naresuan University, 8(2), 57-68.

Murata, K., \& Iino, M. (2017). EMI in higher education: An ELF perspective. In J. Jenkins, W. Baker, \& M. Dewey (Eds.), The Routledge Handbook of English as a Lingua Franca (pp. 400-412). London and New York: Routledge. https://doi.org/10.4324/9781315717173-33

Nomnian, S. (2014). English as the ASEAN lingua franca in Thai Higher Education. Veridian E-Journal, Silpakorn University, International Humanities, Social Sciences and arts, 7(4), 75-84.

Norton, B. (1997). Language, identity, and the ownership of English. TESOL quarterly, 31(3), 409-429. https://doi.org/10.2307/3587831

Norton, B. (2018). Identity and the ownership of English. In A. Pavlenko (Ed.), The nonnative English teacher, TESOL Encyclopedia of English Language Teaching. Wiley. https://doi.org/10.1002/9781118784235.eelt0030

Oda, M., \& Toh, G. (2018). Significant Encounters and Consequential Eventualities: A Joint Narrative of Collegiality Marked by Struggles Against Reductionism, Essentialism and Exclusion in ELT. In B. Yazan \& N. Rudolph (Eds.), Criticality, Teacher Identity, and (In)equity in English Language Teaching (pp. 219-236). Educational Linguistics, 35. Springer, Cham. https://doi.org/10.1007/978-3-319-72920-6_12

Passakornkarn, S., \& Vibulphol, J. (2020). Development of World Englishes-Based Listening Materials to Raise the Awareness of the Varieties of English for Thai EFL Upper Secondary School Students. LEARN Journal: Language Education Acquisition Research Network, 13(1), 225-246.

Pennycook, A. (1994). The Cultural Politics of English as an International Language. London: Longman.

Phillipson, R. (1992). Linguistic Imperialism. Oxford: Oxford University Press.

Phothongsunan, S., \& Suwanarak, K. (2008). Native and non-native dichotomy: Distinctive stances of Thai teachers of English. Abac Journal, 28(2).

Pongsirijan, M., Wongrak, C., Kookiattikoon, S., \& Puangsuk, O. (2019). When Beautiful Thai Smiles Do Not Count: CLT for Receiving Compliments in English. REFLections, 26(1), 30-57.

Prabjandee, D. (2020). Teacher professional development to implement Global Englishes language teaching. Asian Englishes, 22(1), 52-67. https://doi.org/10.1080/13488678.2019.1624931

Rattanaphumma, R. (2013). Accents and Teaching Practices: Roles and Implications for Language Teaching and Learning in the Expanding Circle. Paper presented at the Proceedings of The Fifth International Conference of English as a Lingua Franca.

Saengboon, S. (2015). An Exploratory Study of Thai University Students' Understanding of World Englishes. English Language Teaching, 8(11), 131-154. https://doi.org/10.5539/elt.v8n11p131

Saengngoen, J. (2014). Native-speakerism: Non-white and non-native English teachers in the ESL/EFL field with a focus on Thailand and Southeast Asia. Department of Language, Literacy, Sociocultural Studies, University of New Mexico, Albuquerque, USA.

Snodin, N. S., \& Young, T. J. (2015). 'Native-speaker' varieties of English: Thai perceptions and attitudes. Asian Englishes, 17(3), 248-260. https://doi.org/10.1080/13488678.2015.1083354

Suizu, A., \& Aung, M. T. T. (2018). Native Speakerism in English Teacher Education in Asian EFL: Cases of Japan, Thailand, and Myanmar. Paper presented at the 43rd National Conference: The Japanese Association for Asian Englishes, Hosei University, Japan.

Sukamolson, S. (1998). English Language Education Policy in Thailand. Asian Englishes, 1(1), 68-91. https://doi.org/10.1080/13488678.1998.10800995

Suksiripakonchai, W. (2013). Thai students' attitudes towards native/non-native speakers of English. Academic Journal of Humanities and Social Sciences Burapha University, 21(35), 49-68. 
Suwanarak, K. (2010). Can only native English speaking teachers teach aural and oral skills? ABAC Journal, 30(2), 43-63.

Tahmasbi, S., Hashemifardnia, A., \& Namaziandost, E. (2019). Standard English or world Englishes: Issues of ownership and preference. Journal of Teaching English Language Studies, 7(3), 83-98.

Tananuraksakul, N. (2017). Building up Thai EFL students' positive attitudes toward their non-native English accented speech with the use of phonetic website. Teaching English with Technology, 17(4), 52-63.

Tarrayo, V. N., Ulla, M. B., \& Lekwilai, P. (2021). Perceptions toward Thai English: A study of university English language teachers in Thailand. Critical Inquiry in Language Studies, 1-24. https://doi.org/10.1080/15427587.2021.1919113

Tassev, V. V. (2020). University Students' Preferences of Assessing Levels of Intelligibility and Comprehensibility of Native English Teachers'(NETs) Accents Compared to Non-native English Teachers'(NNETs) Accents: A Case-Study with Undergraduate Students at Huachiew Chalerm. Asian Journal of Literature, Culture and Society, 9(2), 1-25.

Tassev, V. V. (2021a). Students' Perspectives on Perceived Levels of Intelligibility and Comprehensibility: Comparing the Accents of Native English Teachers (NETs) with Those of Non-Native English Teachers (NNETs). Sisaket Rajabhat University Journal, 15(1), 143-160.

Tassev, V. V. (2021b). Undergraduate University Students' Views regarding Intelligibility and Comprehensibility of the Pronunciation of Native English Teachers'(NETs) versus Non-native English Teachers'(NNETs') Pronunciation-A Case-Study at Assumption University of Thailand (AU). The New English Teacher, 15(1), 24-35.

Teng, B., \& Sinwongsuwat, K. (2015). Teaching and Learning English in Thailand and the Integration of Conversation Analysis (CA) into the Classroom. English Language Teaching, 8(3). https://doi.org/10.5539/elt.v8n3p13

Walkinshaw, I., \& Oanh, D. H. (2014). Native and non-native English language teachers: Student perceptions in Vietnam and Japan. Sage Open, 4(2), 1-9. https://doi.org/10.1177/2158244014534451

Watson Todd, R. (2006). The myth of the native speaker as a model of English proficiency. rEFLections, 8, 1-7.

Widdowson, H. G. (1994). The ownership of English. TESOL quarterly, 28(2), 377-389. https://doi.org/10.2307/3587438

\section{Note}

Note 1. In fact, according to Jenkins (2006) and Jenkins et al. (2011), ELF and WEs can be complementing paradigms, not competing ones. This is because they share certain similarities including their emphasis on plurilithic English and English variation.

\section{Copyrights}

Copyright for this article is retained by the author(s), with first publication rights granted to the journal.

This is an open-access article distributed under the terms and conditions of the Creative Commons Attribution license (http://creativecommons.org/licenses/by/4.0/). 